\title{
18
}

\section{Low-Flow Modification of Flood Control Channels in Cities}

\section{Celia Fan, James Li, Grace Luk and Onyx Wai}

Many rivers and streams throughout the world have been severely affected by human activities in the past century including water abstraction, watershed land use changes, power generation, and dam and levee construction. In cities, engineering practices advocate straightening, enlarging, and converting the natural rivers and streams into concrete channels to maximize the efficiency of conveying the floodwaters away from populated areas. These engineering structures disrupt the natural equilibrium of fluvial systems and eliminate macroinvertebrates and aquatic and riparian species in watercourses. With a growing awareness of the value of the natural riverine ecosystems, a global movement of river management has shifted from manipulation and control to restoration and conservation in the past decade (Hammersmark and Mount, 2005; MTO, 1997; Bockelmann et al., 2002; Ness and Joy, 2002; Doll et al., 2003). The objective of this research is to develop a general stream restoration approach for providing low flow habitat in flood control channels in highly urbanized areas. The restoration goals are: (i) to provide a natural and selfsustainable river and geomorphic system; (ii) to establish appropriate pools and riffles and in-stream covers for extending and providing a better living conditions of the aquatic habitats; and (iii) to maintain flood control function. A concrete flood channel in Yuen Long, Hong Kong, that drains into a nature reserve, the Mai Po Nature Reserve in Deep Bay, will be used as a pilot site to demonstrate the design methodology and application of the flood channel restoration approach. Meanders, deflectors and instream covers will be applied to the

Fan, C., J. Li, G. Luk and O. Wai. 2010. "Low-Flow Modification of Flood Control Channels in Cities." Journal of Water Management Modeling R236-18. doi: 10.14796/JWMM.R236-18.

(C) CHI 2010 www.chijournal.org ISSN: 2292-6062 (Formerly in Dynamic Modeling of Urban Water Systems. ISBN: 978-0-9808853-3-0) 
low-flow channel for pools and riffles creation in order to achieve the restoration goals.

\subsection{Past River Restoration Projects}

\subsubsection{Colonial Creek in Waterloo, Ontario, Canada}

Colonial Creek in Waterloo, Ontario, Canada was the first project in Ontario that involved the removal of a concrete trapezoidal channel and the restoration of a natural channel and flood plain. Waterloo is a suburban city, with a population of approximately 97500 , located in southern Ontario. The creek flows through an old, developed commercial and residential areas with some upstream stormwater quantity controls. The flood plain was excavated and a meandering $\mathrm{C}$ channel from Rosgen's natural channel design method (Rosgen, 1994; 2006a; 2006b) with a balanced pool-riffle sequence was created. Fascines, brush mattresses, and river stone bed material were used to stabilize the channel and the flood plain. This restoration project was an excellent example of how an extremely altered and unnatural channel system can visually become a naturalized and ecologically functioning system. Restoring the connection to the flood plain is an important flood control feature of this project to capture the remaining runoff when the natural channel exceeds the bankfull discharge conditions. Unfortunately, biological or water quality monitoring was not available at this site to support the improvement of the fluvial system (Harrington, 2003).

\subsubsection{The River Cole in Coleshill, England}

The River Cole is a tributary of the River Thames located in the upper part of the Cole catchment. The Cole catchment is rural and is $130 \mathrm{~km}^{2}$ area comprising clay, sand, limestone, and chalk geology. Sediments in the lower reaches, where the river is most modified, are confined to silts and mud. Land use along the River Cole corridors is a mix of grassland, agricultural and industrial areas. The restoration site is located within $6 \mathrm{~km}$ of the River Cole at the village of Coleshill where the floodplain is up to $400 \mathrm{~m}$ wide and graded at about 0.0008 . In the early nineteenth century, the river was straightened for milling purposes. In the 1970s, the river was further deepened and widened to reduce flooding of arable land. The principle achievement of the restoration project is the creation a new $2 \mathrm{~km}$ meandering river course that is much smaller 
in size than the previously enlarged channel. The goal of this design is to restore more frequent seasonal flooding to adjacent flood plains. The existing mill by-pass channel remained in operation and was incorporated into the new design by extending it as far upstream as practical to create the additional meandering channel that was required. This restoration project demonstrates other river restoration design approaches that are commonly used in European countries when space is available (Burns, 2002).

\subsubsection{Cheonggyecheon Stream, Seoul, South Korea}

Cheonggyecheon Stream is approximately $5.8 \mathrm{~km}$ long flowing through downtown Seoul, the capital city of South Korea. The stream then meets the Jungnangcheon Stream, which in turn empties into the Han River. In the midnineteenth century, Cheonggyecheon Stream was covered over with concrete for roads construction. In 1968, an elevated highway was built over it. In July 2003 , a large restoration project was initiated to remove the highway and uncover the stream. The cost of the project was about US\$900 million and $120000 \mathrm{t}$ water had to be pumped out from the stream everyday during the construction process. The new design has the stream bed material fully mounted on the concrete channel to avoid erosion problems. It removes much of the natural system that would be beneficial in the restoration and may hamper invertebrate and other habitat. The stream was re-opened to the public in September 2005 and lauded as a major success in urban renewal and beautification. This project demonstrates how to apply river restoration techniques on a concrete channel in highly urbanized areas. However, the entire design, such as the non-movable bed and all the features associated with the concrete channel, is more towards an artificial approach rather than naturalization and a selfsustainable approach (Shin, 2004). Although the historical conditions and watershed contributions considerations is success in this project, the improvement of the fish habitat (is it a living environment suitable for spawning?) is still questionable.

The above discussion has provided a general background review of several significant river and stream restoration projects around the world. Information gathered from these examples indicates that the geographical and physical characteristics along with existing management inform the stream or river restoration practices and design that can lead to successful restorations. For instance, the stream and river restoration approaches commonly applied in North America and European countries may not be fully adaptable to highly urbanized population centres in Asia, such as Seoul and Hong Kong, due to the 
extremely compacted space along the channel corridors and their application on flood control concrete channels especially under monsoon conditions. In North America, concrete channels were widely used on different sections of a stream for flood control, erosion control and bank protection over the past decades. Current stream restoration practices in North America for less urban environments tend to restore the natural channel and reconnect the floodplain area to the stream if conditions are suitable. These practices are almost impossible to apply to the flood control concrete channels in highly urbanized areas due to the large quantity of runoff during heavy thunderstorm events. Thus, stream restoration practices in highly urbanized areas should be applied directly to the concrete channels while maintaining the flood control function. Currently, there is no formal documentation and limited research on a general approach to use of concrete channels as a part of stream restoration for flood control in highly urbanized areas. This research will address the research needs and focus on the development of a general stream restoration approach for flood control concrete channels in highly urbanized areas. The approach consists of four phases: (i) modification of the low-flow channel based on the swimming velocity of the fish habitat; (ii) development of hydraulic and sediment transport relationships for the modified low-flow channel; (iii) application of deflectors in proper locations which maximizes the pools volume for fish habitats; and (iv) confirmation of the original flood control function after stream restoration. To validate the numerical model used in phases (ii) and (iii), a physical model representing a $2 \mathrm{~m}$ wide meander low-flow channel section will be constructed at The Hong Kong Polytechnic University's Hydraulics Laboratory.

\subsection{Flood Channels Restoration Approach}

The different phases of the river restoration approach for flood control channels are illustrated in Figure 18.1. Prior the modification of the low-flow channel, a stream assessment should be conducted along the studying area (Figure 18.2) to collect information such as flow rates under different flow regimes, channel geometry, sediment size distribution, water quality, and potential existing living habitats. The low-flow channel will then be modified by manipulating the existing meander patterns near the studying area. The cross-section area of the lowflow channel will be adjusted in order to hold the proposed bed material. The flow velocity of the modified low-flow channel should be within the range of the swimming velocity for the targeted fish habitats. Deflectors and other obstacles that encourage the pool formation will be applied to different locations in order to speed up the pool creation naturally (Figure 18.3) and provide shad- 
ing areas for aquatic species. The optimal locations of single and double deflectors along a meander low-flow channel section were determined using physical model experiments. Once the modification of the low-flow channel is finished, numerical model experiments will be used to validate the design for different weather conditions.

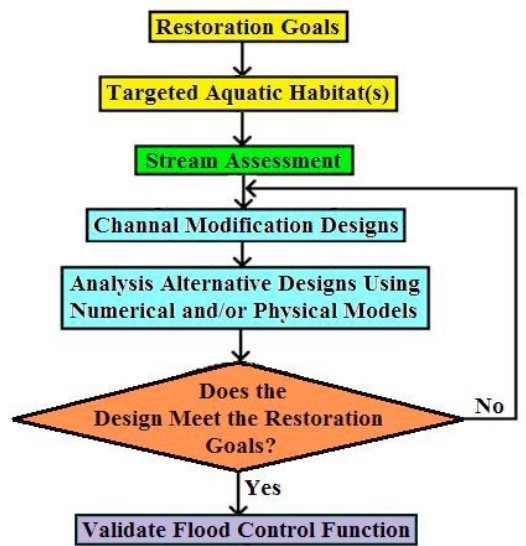

Figure 18.1 Flowchart of environmental restoration approach for flood control channels.

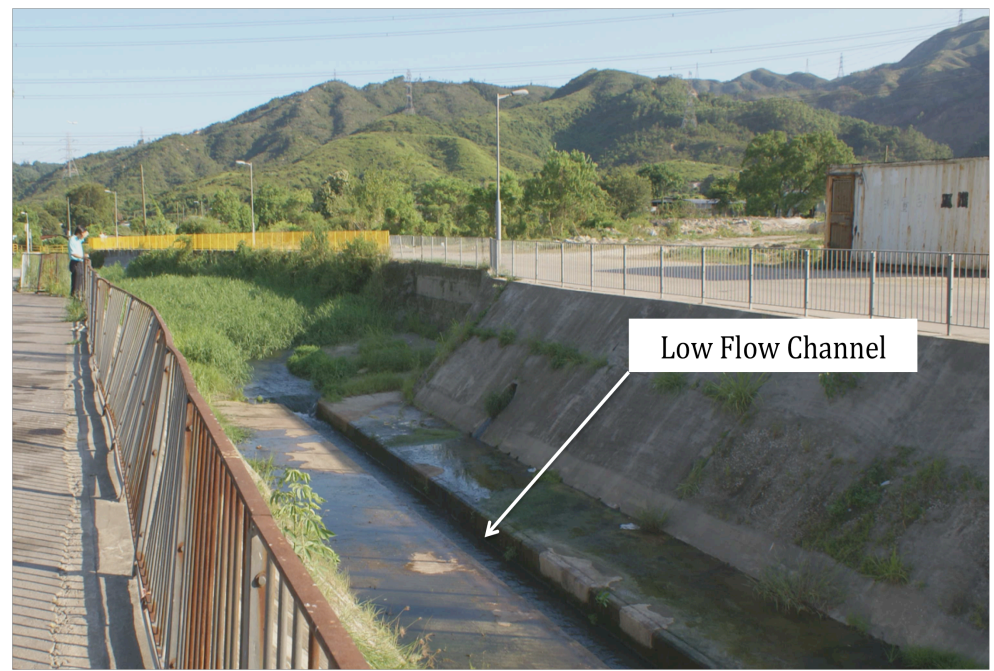

Figure 18.2 Typical flood control concrete channel in Yuen Long, Hong Kong, which the entrance of the channel is connected to a natural area. 


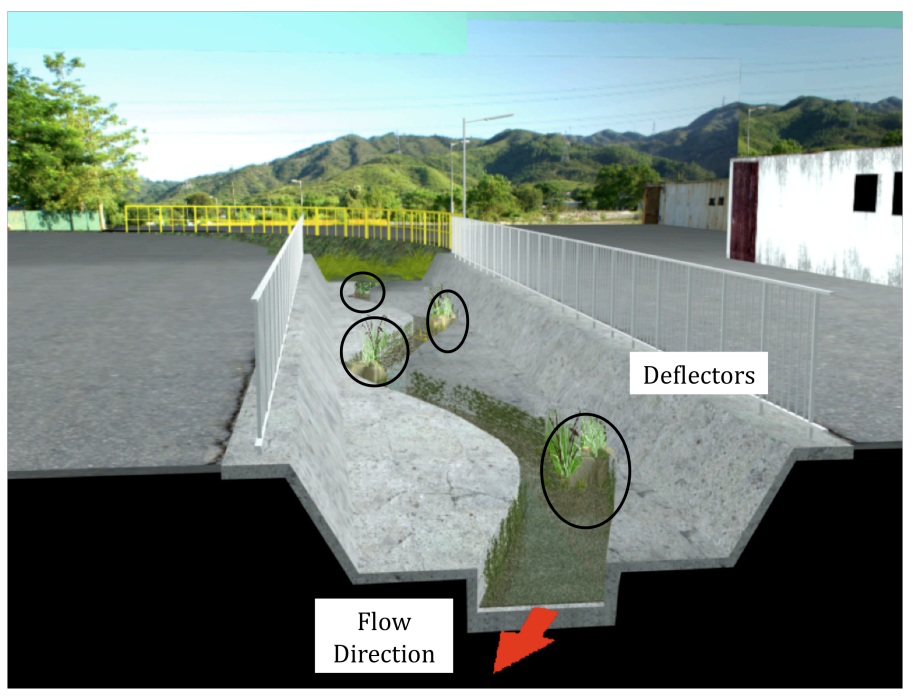

Figure 18.3 Modified low-flow channel design.

There are four proposed scenarios for the numerical model studies: (i) modified low-flow channel with bed material; (ii) modified low-flow channel with deflectors and bed material; (iii) modified low-flow channel without bed material; and (iv) modified low-flow channel with deflectors and without bed material. The last two scenarios investigate the bed re-establishment process after a severe thunderstorm event. Deflectors are applied in scenarios (ii) and (iv) to investigate its effects on maximizing pools creation along the modified low-flow channel. Information collected from the physical model experiments will be used for numerical model calibration.

\subsection{Conclusions}

A general environmental restoration approach for providing better low flow habitat in existing flood control channels is in the development process in response to the global awareness and recognized value of natural riverine ecosystems. A pilot site in Hong Kong will be used to demonstrate this restoration approach for improving habitat conditions within highly urbanized systems. Physical and numerical models will be developed to inform and improve the living conditions of in-stream habitats in modified low-flow channels while maintaining current flood control functions. 


\section{Acknowledgments}

This research was supported by Hong Kong Research Grants Council Project No. BQ688 and the Natural Sciences and Engineering Research Council of Canada (NSERC) Research Grants. Additional funding was sought from the Internal Competitive Research Grant of The Hong Kong Polytechnic University (Project No. GYG57).

\section{References}

Bockelmann, B.N., Fenrich, E.K., Lin, B. and Falconer, R.A. (2003). "Development of an Ecohydraulics Model for Stream and River Restoration.” Ecological Engineering, 22: 227-235.

Burns, R. (2002). Manual of River Restoration Techniques. River Restoration Centre, Bedfordshire, UK. Website: < http://www.therrc.co.uk/rrc_manual_pdf.php > (June 10, 2008).

Doll, B.A., Grabow, G.L., Hall, K.R., Halley, J., Harman, W.A., Jennings, G.D. and Wise, D.E. (2003). Stream Restoration: A Natural Channel Design Handbook, NC Stream Restoration Institute, NC State University. Website:

$<$ http://www.bae.ncsu.edu/programs/extension/wqg/sri/stream_rest_guidebook/ guidebook.html $>$ (May 2, 2007).

Hammersmark, C.T. and Mount, J.F. (2005). Geomorphic, Hydrologic and Ecological Effects of the Bear Creek Meadow Restoration Project: A Layman's Review. UC Davis, Center for Watershed Sciences.

Harrington, G.D. (2003). Urban Stream Restoration Projects, Harrington \& Hoyle Limited, ON, Canada. Website:

$<$ http://www.harrington-hoyle.com/urbanstream.htm > (August 20, 2008).

Ness, R. and Joy, D.M. (2002). "Performance of Natural Channel Designs in Southwestern Ontario." Canadian Water Resources Journal, 27(3): 293-315.

Ontario Ministry of Transportation (MTO). (1997). Drainage Management ManualPart 3, Drainage and Hydrology Section, Transportation Engineering Branch, Quality and Standards Division. Ministry of Transportation, Toronto, Ontario, Canada.

Rosgen, D.L. (1994). “A Classification of Natural Rivers.” Catena, 22: 169-199.

Rosgen, D.L. (2006a). The Application of Stream Classification Using the Fluvial Geomorphology Approach for Natural Channel Design: The Rest of the Story, Wildland Hydrology Consultants, CO, USA. Website:

$<$ http://www.wildlandhydrology.com/html/references_html $>$ (May 11, 2008).

Rosgen, D.L. (2006b). "River Restoration Using a Geomorphic Approach for Natural Channel Design." Proceedings of the 8th Federal Interagency Sediment Conference, Reno, NV, USA, 1: 394-401.

Shin, J.H. (2004). "Dream and Hope of Korea, Cheonggyecheon Restoration.” Magazine of Korean Water Resources Association, 37(1). 